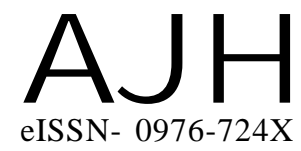

Article history :

Received : 10.10 .2014

Revised : 12.04.2015

Accepted : 18.05.2015
Members of the Research Forum

Associated Authors:

${ }^{1}$ Department of Horticulture, B.A.

College of Agriculture, Anand

Agricultural University, ANAND (GUJARAT) INDIA
Author for correspondence : H.N. LEUA

Horticulture Polytechnic, Agriculture Experimental Station (N.A.U.) PARIA (GUJARAT) INDIA Email : hasmukh.hort@gmail.com
THEASIAN JOURNAL OF HORTICULTURE

Volume 10 | Issue 1 | June, 2015 | 126-129

Visit us -www.researchjournal.co.in

\title{
Effect of integrated nitrogen management on growth, flowering and flower yield of gaillardia (Gaillardia pulchella Foug.) cv. LORENZIANA under middle Gujarat conditions
}

\section{A.S. PATEL ${ }^{1}$, H.N. LEUA, N.S. PAREKH ${ }^{1}$ AND H.C. PATEL ${ }^{1}$}

ABSTRACT : A field experiment on effect of integrated nitrogen management on growth, flowering and flower yield of gaillardia (Gaillardia pulchella Foug) cv. LORENZIANA under middle Gujarat conditions was conducted at Horticulture Research Farm, Department of Horticulture, B.A. College of Agriculture, Anand Agricultural University, Anand during the year 2009-10. The treatments comprised of organic fertilizers, biofertilizer and three level of nitrogen $(100,75$ and $50 \mathrm{~kg} \mathrm{~N} / \mathrm{ha})$ including control $100 \mathrm{~kg} \mathrm{~N} / \mathrm{ha}+\mathrm{FYM} 10 \mathrm{t} / \mathrm{ha}$ were tried in Randomized Block Design with three replications. The results revealed that application of $75 \mathrm{~kg}$ $\mathrm{N} /$ ha + vermicompost $3.75 \mathrm{t} /$ ha produced significantly maximum plant height $(73.33 \mathrm{~cm})$, number of branches per plant (36.98) and plant spread $(72.68 \mathrm{~cm}$ in north - south direction and $68.59 \mathrm{~cm}$ in east - west direction). Same treatment recorded significantly minimum days for first flower initiation, 50 per cent flowering, maximum number of flowers per plant, maximum flower diameter as well as weight of individual flower. Significantly maximum flower yield per plant and hectare were recorded in the same treatment. The treatment of $50 \mathrm{~kg} \mathrm{~N} / \mathrm{ha}+\mathrm{FYM} 20 \mathrm{t} / \mathrm{ha}$ obtained maximum shelf-life of flower (1.80 days) as compared to control.

KEY WORDS : Organic fertilizer, Biofertilizer, Nitrogenous fertilizer, Gaillardia

HOW TO CITE THIS ARTICLE : Patel, A.S., Leua, H.N., Parekh, N.S. and Patel, H.C. (2015). Effect of integrated nitrogen management on growth, flowering and flower yield of gaillardia (Gaillardia pulchella Foug.) cv. LORENZIANA under middle Gujarat conditions. Asian J. Hort., 10(1) : 126-129. 